\title{
Pengaruh pelatihan kader yandu lansia dalam menciptakan desa ramah dan sehat bagi lansia di Desa Purwobinangun, Sleman
}

\author{
Sumarni, ${ }^{1, *}$ Adi Heru Sutomo, ${ }^{2}$ Cempaka Tursina, ${ }^{3}$ Purwanta, ${ }^{4}$ Ade Indah Wahdini, ${ }^{1}$ \\ Nanda Kusumaningrum ${ }^{1}$ \\ ${ }^{1}$ Departemen Kedokteran Jiwa, Fakultas Kedokteran, Kesehatan Masyarakat, dan Keperawatan \\ Universitas Gadjah Mada, Yogyakarta, Indonesia \\ ${ }^{2}$ Departemen Kedokteran Keluarga, Komunitas, dan Bioetika, Fakultas Kedokteran, Kesehatan \\ Masyarakat, dan Keperawatan, Universitas Gadjah Mada, Yogyakarta, Indonesia \\ ${ }^{3}$ Departemen Ilmu Penyakit Saraf, Fakultas Kedokteran, Kesehatan Masyarakat, dan Keperawatan \\ Universitas Gadjah Mada, Yogyakarta, Indonesia \\ ${ }^{4}$ Departemen Keperawatan Jiwa dan Komunitas, Fakultas Kedokteran, Kesehatan Masyarakat, dan \\ Keperawatan, Universitas Gadjah Mada, Yogyakarta, Indonesia
}

\section{Submitted: 24 November 2018 Revised: 25 Januari 2019 Accepted: 27 januari 2019}

\begin{abstract}
ABSTRAK Erupsi Gunung Merapi merupakan bencana alam yang mengakibatkan trauma psikologis bagi lansia. Lansia berisiko mengalami depresi, disabilitas dan menurunkan kualitas hidup sehingga perlu dilakukan penanganan terkait kesehatan dan kualitas hidup lansia yaitu dengan memberikan pendampingan yang berkelanjutan pada kader yandu lansia dalam menciptakan desa ramah dan sehat lansia. Tujuan penelitian ini adalah mengetahui pengaruh peningkatan pengetahuan dan keterampilan kader yandu lansia dalam menciptakan desa ramah dan sehat bagi lansia di Desa Purwobinangun, Sleman. Penelitian ini menggunakan data sekunder dari pengabdian masyarakat pada bulan Mei sampai September 2018 di Desa Purwobinangun, Sleman. Sasaran pengabdian masyarakat tersebut adalah 53 kader yandu lansia dan 80 lansia di Desa Purwobinangun, Sleman. Instrumen yang digunakan adalah modul peningkatan kapasitas kader untuk desa ramah dan sehat lansia, geriatric deppression scale (GDS), mini mental state examination (MMSE), kuesioner pengetahuan dan keterampilan permainan lokal, deteksi dini dan penanggulangan kesehatan lansia. Data disajikan secara deskriptif kuantitatif. Setelah diberikan pelatihan, nilai rata-rata pengetahuan penanggulangan permainan kearifan budaya lokal, dukungan sosial dan religius, senam otak, dan ramah lansia meningkat sebanyak 30 poin, 50 poin, 40 poin, dan 50 poin berturut-turut. Perubahan nilai rata-rata keterampilan kader yandu lansia dalam penanggulangan permainan kearifan budaya lokal, dukungan sosial dan religius, senam otak, dan ramah lansia meningkat sebanyak 17,12 poin, 19,18 poin, 28,68 poin, dan 27,58 poin. Untuk perubahan kecenderungan gangguan kesehatan, lansia yang tidak hipertensi meningkat sebanyak 7 orang, untuk lansia yang mengalami diabetes melitus tidak ada perubahan jumlah sebelum dan setelah pelatihan, sedangkan lansia yang mengalami depresi turun sebanyak 18 orang. Untuk lansia yang mengalami gangguan kognitif turun sebanyak 18 orang dan lansia yang memiliki kualitas hidup tinggi meningkat sebesar 22 lansia. Pelatihan yandu lansia dapat meningkatkan pengetahuan dan keterampilan kader yandu lansia dalam penangulangan gangguan kesehatan pada lansia.
\end{abstract}

KATA KUNCI depresi; dukungan sosial; kualitas hidup; lansia; permainan lokal

\footnotetext{
*Corresponding author: Sumarni

Departemen Kedokteran Jiwa, Fakultas Kedokteran, Kesehatan Masyarakat, dan Keperawatan, Universitas Gadjah Mada, Jl. Farmako, Sekip Utara Yogyakarta 55281, Indonesia

Email: bu_sumarnidw@yahoo.com
} 
ABSTRACT Merapi eruption can cause a psychological traumatic for elderly such as depression, increase disability, and decrease quality of life. We need to train the cadres to make an elderly care village. The aim of this study is to know the influence of cadre training in knowledge and skill for elderly healthiness. This study uses secondary data from community research on May until September 2018 in Desa Purwobinangun, Sleman. The target is cadres and 80 elderlies in Desa Purwobinangun, Sleman. The instruments in this study such as Module Ramah dan Sehat Lansia, Geriatric Depression Scale (GDS), Mini Mental State Examination (MMSE), questionnaire about knowledge and skills of a traditional games, and questionnaire about early detection and treatment in old age health. The data will be shown in quantitative data. After trained, the average value of the knowledge of coping with local cultural wisdom games, social and religious support, brain gymnastics, and friendly elderly increased by 30 points, 50 points, 40 points, and 50 points respectively. Changes in the average value of the skills of elderly yandu cadres in tackling local cultural wisdom games, social and religious support, brain gymnastics, and friendly elderly have increased by 17.12 points, 19.18 points, 28.68 points, and 27.58 points. For changes in the trend of health problems, the elderly who are not hypertensive increased by 7 people, for the elderly who have diabetes mellitus there was no change in the number before and after training, while the elderly who experienced depression fell by 18 people. For the elderly who experience cognitive impairment decreased by 18 people and elderly who have high quality of life increased by 22 elderly. Yandu training for the elderly can improve the knowledge and skills of the elderly yandu cadre in the management of health problems in the elderly. Cadres empowerment can increase knowledge and skill of cadre to treat health problem in elderly.

KEYWORDS depression; social support; quality of life; elderly; traditional games

\section{Pendahuluan}

Kesehatan lansia harus diperhatikan agar lansia sejahtera di usia senja. Sejak tahun 2000, Indonesia memasuki era masyarakat berstruktur tua (ageing structured population). Data sensus penduduk tahun 2010 menunjukkan bahwa jumlah lansia di Daerah Istimewa Yogyakarta (DIY) mencapai 12\% dari jumlah penduduk dengan pertumbuhan $1,02 \%$ per tahun. Di Kabupaten Sleman, proporsi jumlah penduduk lansia pada tahun 2012 mencapai 10,7\%, sedangkan proporsi penduduk lansia awal (usia 5559 tahun) sebesar 3,69\% dari jumlah penduduk. ${ }^{1}$ Data sensus penduduk tahun 2015 menunjukkan bahwa Provinsi DIY mengalami peningkatan pertumbuhan lansia dari $0,7 \%$ menjadi $1,02 \%$. Jumlah lansia di DIY mencapai $13,4 \%$ dari total jumlah penduduk sehingga pada 10 tahun ke depan di DIY diperkirakan akan terjadi ledakan jumlah penduduk lansia. ${ }^{2}$

DIY merupakan provinsi yang paling perlu diperhatikan karena mempunyai angka harapan hidup lansia tertinggi se-Indonesia. Usia harapan hidup lansia di Kabupaten Sleman mencapai lebih dari 72 tahun. ${ }^{2}$ Proses menua merupakan proses yang secara alamiah terjadi terus-menerus atau berkelanjutan dan umumnya dialami oleh semua makhluk hidup. Manusia akan mengalami kemunduran baik struktur maupun fungsi organnya. Keadaan tersebut dapat menyebabkan berkurangnya kemampuan beradaptasi terhadap lingkungan. Menua adalah proses yang kompleks, meliputi aspek biologi, psikososial, budaya, dan perubahan pengalaman ${ }^{3}$.

Perubahan-perubahan fisik yang terjadi meliputi terdapatnya penyakit kronis, penyakit degeneratif, dan sindrom metabolik, misalnya diabetes melitus, hipertensi, hiperkolesterolemia, obesitas, dan dislipidemia. Sindrom metabolik prevalensinya meningkat pada usia lanjut. Berbagai macam penyakit degeneratif dan penyakit kronis akan meningkatkan risiko gangguan jiwa. Sindrom metabolik juga dapat memicu terjadinya depresi. ${ }^{4}$

Depresi pada lansia merupakan hasil interaksi dari 3 faktor yaitu faktor biologi yang berupa hilangnya sejumlah neuron di otak, genetik, dan 
penyakit fisik; faktor psikologi yang berupa rasa rendah diri dan kurang rasa keakraban; serta faktor sosial yang berupa kesepian dan gangguan interaksi sosial. ${ }^{4}$ Depresi dapat menyebabkan gangguan pikir, bunuh diri, gangguan tidur, serta gangguan interaksi sosial, kognitif, dan memori. Depresi dapat menimbulkan dan memperberat penyakit degeneratif dan sindrom metabolik. ${ }^{4}$

Berdasarkan analisis masalah yang dapat terjadi pada lansia, dibutuhkan suatu upaya agar kesehatan lansia meningkat. Salah satu upaya untuk meningkatkan kesehatan lansia yaitu dengan memberikan pelatihan tentang memberikan sikap ramah terhadap lansia, memberikan pelatihan permainan kearifan budaya lokal, serta memberikan pelatihan dukungan sosial dan spiritual kepada kader yandu lansia. Kader yandu lansia merupakan salah satu perangkat desa yang mengurus semua kebutuhan terkait kesehatan lansia.

Saat ini masih sedikit penelitian mengenai efektivitas pelatihan pengetahuan dan keterampilan terkait deteksi dini depresi dan penanggulangan depresi pada lansia. Penulis tertarik untuk mengetahui pengaruh peningkatan pengetahuan dan keterampilan kader yandu lansia dalam menciptakan desa ramah dan sehat bagi lansia di Desa Purwobinangun, Sleman.

\section{Metode}

Pelatihan dilakukan pada bulan Juni sampai Oktober 2017 di Desa Purwobinangun, Sleman. Sasaran pelatihan adalah 53 kader yandu lansia dan 80 lansia di Desa Purwobinangun, Sleman. Instrumen penelitian yang digunakan adalah modul peningkatan kapasitas kader untuk menciptakan desa ramah dan sehat bagi lansia, instrumen geriatric deppression scale (GDS), mini mental state examination (MMSE), kuesioner tentang pengetahuan dan keterampilan permainan berbasis kearifan budaya lokal, serta kuesioner pengetahuan dan keterampilan deteksi dini dan penanggulangan depresi dengan dukungan sosial. Data disajikan secara deskriptif kuantitatif. Sebelum dan setelah pelatihan, dilaksanakan pre-test dan post-test.

\subsection{Pre-test}

Sebelum dilakukan pelatihan, dilakukan pemeriksaan awal tekanan darah dan status gizi, pengukuran tingkat depresi dengan instrumen GDS, fungsi kognitif menggunakan MMSE, dan penilaian kualitas hidup lansia serta pengukuran tingkat pengetahuan dan keterampilan kader yandu lansia tentang cara bersikap ramah terhadap lansia, senam otak, permainan berbasis kearifan budaya lokal, dan penanggulangan depresi lansia secara sosial spiritual.

\subsection{Intervensi}

Tim peneliti memberikan pelatihan cara bersikap ramah dan menghargai lansia, senam otak dan permainan berbasis kearifan budaya lokal kepada kader yandu lansia di Balai Desa Purwobinangun, sebanyak 6 kali pertemuan, masing-masing selama 2 jam, dalam waktu enam minggu. Setiap pertemuan berisi dua paket pelatihan ramah terhadap lansia, dua paket permainan berbasis kearifan budaya lokal dan dua paket senam otak.

Tim peneliti juga memberikan pelatihan penanggulangan depresi pada lansia secara sosial spiritual kepada kader yandu lansia Desa Purwobinangun, sebanyak 2 kali pertemuan, masing-masing selama 2 jam, dalam waktu dua minggu. Setiap pertemuan berisi cara-cara atau pendekatan dukungan sosial secara emosional, penghargaan, intrumental, informatif, dan spiritual.

Setelah kader diberikan pelatihan-pelatihan tersebut, tim peneliti mendampingi kader dalam memberikan intervensi kepada lansia.

\subsection{Post-test}

Setelah intervensi dilakukan, tim peneliti melakukan pemeriksaan tekanan darah dan status gizi, derajat depresi dan fungsi kognitif pada lansia dengan instrumen GDS dan MMSE, serta penilaian kualitas hidup lansia. Tingkat pengetahuan dan keterampilan kader dalam memberikan sikap ramah terhadap lansia, senam otak, permainan berbasis kearifan budaya lokal, dan penanggulangan depresi lansia secara sosial spiritual juga dinilai kembali. Hasil pretest dan post-test kemudian dibandingkan. 
Tabel 1. Karakteristik kader yandu lansia di Desa Purwobinangun( $n=53)$

\begin{tabular}{lcc}
\hline Karakteristik & $\mathbf{n}$ & $\mathbf{\%}$ \\
\hline Umur & & \\
$\quad 30-45$ tahun & 11 & 20,75 \\
$\quad 46-55$ tahun & 36 & 67,92 \\
$\quad>55$ tahun & 6 & 11,32 \\
$\begin{array}{l}\text { Pendidikan } \\
\quad \text { SMP }\end{array}$ & 16 & 30,18 \\
SMA/SMK & 39 & 73,58 \\
$\quad$ PT & 8 & 15,09 \\
Pekerjaan & & \\
$\quad$ Ibu Rumah Tangga & 25 & 47,16 \\
$\quad$ Petani & 16 & 30,18 \\
$\quad$ Pengawai Negeri Sipil & 12 & 22,64 \\
\hline
\end{tabular}

SMP: sekolah menengah pertama; SMA: sekolah menengah atas; SMK: sekolah menengah kejuruan; PT: perguruan tinggi

\section{Hasil}

\subsection{Karakteristik kader yandu lansia di Desa} Purwobinangun

Kader yandu lansia di Desa Puwobinangun merupakan wanita dewasa yang masih tergolong produktif. Sebagian besar kader merupakan lulusan sekolah menengah atas (SMA) atau Sekolah menengah kejuruan (SMK). Hal ini menunjukkan bahwa tingkat pendidikan kader yandu lansia di Desa Purwobinangun cukup baik. Karakteristik kader yandu lansia secara rinci dipaparkan di Tabel 1.

\subsection{Karakteristik lansia di Desa Purwobinangun}

Tabel 2 menunjukkan bahwa sebagian besar lansia pada penelitian ini berusia 55-65 tahun (32 orang, $40 \%$ ). Sisanya adalah lansia dengan usia $>66$ tahun. Menariknya, ada 21 orang $(26,25 \%)$ yang mengikuti kegiatan yandu lansia pada usia lebih dari 75 tahun. Lansia tersebut nampak antusias mengikuti seluruh rangkaian kegiatan. Sebagian lansia juga masih produktif, baik bekerja sebagai pegawai negeri sipil (PNS), maupun menjadi buruh tani (ikut mengolah lahan pertanian orang lain). Sebagian yang lain
Tabel 2. Karakteristik lansia di Desa Purwobinangun $(\mathrm{n}=80)$

\begin{tabular}{lcc}
\hline Karakteristik & $\mathbf{n}$ & $\mathbf{\%}$ \\
\hline Umur & & \\
$55-65$ tahun & 32 & 40,00 \\
$66-75$ tahun & 27 & 33,75 \\
$\quad>75$ tahun & 21 & 26,25 \\
Pendidikan terakhir & & \\
$\quad$ SD/SR & 34 & 42,50 \\
SMP & 19 & 23,75 \\
SMA/SMK & 25 & 31,25 \\
PT & 2 & 2,50 \\
Pekerjaan & & \\
$\quad$ Pensiun & 11 & 13,75 \\
$\quad$ Buruh tani & 36 & 45,00 \\
Ibu rumah tangga/tidak bekerja & 27 & 33,75 \\
Pegawai negeri sipil & 6 & 7,50 \\
Penghasilan & & \\
$\quad<1.000 .000$ & 22 & 27,50 \\
1.000.000 - 2.000.000 & 29 & 36,25 \\
$>2.000 .000$ & 29 & 36,25 \\
\hline
\end{tabular}

SD: sekolah dasar; SR: sekolah rakyat; SMP: sekolah menengah pertama; SMA: sekolah menengah atas; SMK: sekolah menengah kejuruan; PT: perguruan tinggi

merupakan pensiunan, atau sudah tidak bekerja (hanya beraktivitas di rumah). Karakteristik lansia secara rinci dipaparkan pada Tabel 2.

\subsection{Kecenderungan gangguan kesehatan pada lansia di Desa Purwobinangun sebelum pelatihan}

Setelah dilakukan pemeriksaan, diperoleh data seperti yang tertera pada Tabel 3. Terdapat lansia dengan hipertensi sebanyak 52 orang (65\%). Dengan demikian, sebagian besar lansia mengalami hipertensi yang menjadi faktor risiko gangguan kesehatan lainnya. Selain itu, penelitian ini juga menunjukkan bahwa terdapat 37 orang $(46,25 \%)$ yang menderita diabetes melitus.

Setelah dilakukan wawancara dan pengisian kuesioner, didapatkan 57 orang $(71,25 \%)$ lansia mengalami kecenderungan depresi. Angka ini termasuk tinggi. Sebagian lansia juga memiliki 
Tabel 3. Gangguan kesehatan dan kualitas hidup pada lansia di Desa Purwobinangun sebelum pelatihan kader yandu

\begin{tabular}{lcc}
\hline Gangguan kesehatan & \multicolumn{2}{c}{ Distribusi Frekuensi } \\
\cline { 2 - 3 } & $\mathbf{n}$ & $\%$ \\
\hline Hipertensi & 52 & 65 \\
$\quad$ Ya & 28 & 35 \\
$\quad$ Tidak & & \\
Diabetes melitus & 37 & 46,25 \\
$\quad$ Ya & 43 & 53,75 \\
$\quad$ Tidak & & \\
Kecenderungan depresi & 57 & 71,25 \\
$\quad$ Ya & 23 & 28,75 \\
$\quad$ Tidak & & \\
Fungsi kognitif & 16 & 20 \\
$\quad$ Tidak ada gangguan & 55 & 68,75 \\
$\quad$ Gangguan sedang & 9 & 11,25 \\
$\quad$ Gangguan berat & & \\
Kualitas hidup & 29 & 36,25 \\
$\quad$ Tinggi & 51 & 63,75 \\
$\quad$ Rendah
\end{tabular}

kualitas hidup yang rendah (Tabel 3).

\subsection{Perubahan tingkat pengetahuan kader yandu lansia tentang penanggulangan gangguan kesehatan pada lansia setelah pelatihan}

Setelah dilakukan pelatihan, tingkat pengetahuan kader yandu lansia mengenai penanggulangan gangguan kesehatan pada lansia mengalami peningkatan. Nilai pengetahuan terhadap permainan berbasis kearifan budaya lokal mengalami peningkatan sebesar 30 , sedangkan pengetahuan tentang dukungan sosial dan religius mengalami peningkatan nilai rata-rata dari 25,5 menjadi 75,5 . Pengetahuan tentang senam otak dan ramah lansia juga mengalami peningkatan nilai sebesar 40 dan 50 (Tabel 4).

3.5 Perubahan tingkat keterampilan kader yandu lansia dalam penanggulangan gangguan kesehatan pada lansia setelah pelatihan

Keterampilan kader yandu lansia dalam penanggulangan gangguan kesehatan pada lansia meningkat setelah diberikan pelatihan. Peningkatan keterampilan yang paling tinggi adalah keterampilan kader yandu lansia dalam mempraktikkan cara bersikap ramah terhadap lansia $(28,68)$. Sedangkan peningkatan keterampilan terendah ditemukan pada aspek pemberian dukungan sosial, yaitu hanya sebesar 19,81 (Tabel 5).

\subsection{Perubahan kecenderungan gangguan kesehatan pada lansia di Desa Purwobinangun setelah pelatihan}

Setelah kader yandu lansia dibekali pengetahuan dan keterampilan dalam deteksi dini dan penanggulangan gangguan kesehatan pada lansia dan mengimplementasikannya pada lansia, dilakukan pemeriksaan ulang gangguan kesehatan yang dialami oleh lansia di Desa Purwobinangun.

Lansia yang mengalami hipertensi turun 7 orang, yaitu dari 52 orang menjadi 45 orang. Hal tersebut menunjukkan bahwa pelatihan berdampak baik dan dirasakan langsung oleh lansia. Kader menjadi lebih paham bagaimana mengenali, mendeteksi dini, dan melakukan manajemen terhadap hipertensi dan diabetes melitus. Tidak hanya mahir dalam melakukan pengukuran tekanan darah, namun kader juga paham bagaimana mengajak lansia melakukan manajemen hipertensi secara tepat. Kader yandu lansia juga semakin paham bagaimana manajemen diabetes melitus pada lansia.

Lansia yang mengalami kecenderungan depresi mengalami penurunan sebanyak 18 orang. Selain itu, fungsi kognisi dan kualitas hidup lansia juga semakin baik. Hal tersebut menunjukkan bahwa pelatihan memberikan dampak yang baik dan langsung terhadap kesehatan jiwa dan kualitas hidup lansia. Selama pelatihan kader memberikan dukungan sosial dan religius dengan memberikan perhatian, kasih sayang, penghargaan, nasihatnasihat, dan menampakkan sikap ramah kepada lansia. Pelaksanaan permainan berbasis kearifan budaya lokal membuat lansia tertawa dan bahagia. Lansia juga berlatih untuk melakukan senam revitalisasi otak yang dapat meringankan dan mencegah gangguan fungsi kognitif yang sering 
Tabel 4. Perubahan tingkat pengetahuan kader yandu lansia tentang penanggulangan gangguan kesehatan pada lansia setelah dilakukan pelatihan

\begin{tabular}{lccc}
\hline \multirow{2}{*}{ Pengetahuan penanggulangan } & \multicolumn{2}{c}{ Nilai rata-rata } & \multirow{2}{*}{ Perubahan } \\
\cline { 2 - 4 } & Sebelum & Setelah & \\
\hline Permainan kearifan budaya lokal & 60,5 & 90,5 & +30 \\
Dukungan sosial dan religius & 25,5 & 75,5 & +50 \\
Senam otak & 25,5 & 65,5 & +40 \\
Ramah lansia & 35,5 & 80,5 & +50 \\
\hline
\end{tabular}

Tabel 5. Perubahan tingkat keterampilan kader yandu lansia dalam penanggulangan gangguan kesehatan pada lansia setelah dilakukan pelatihan

\begin{tabular}{lccc}
\hline \multirow{2}{*}{ Keterampilan penanggulangan } & \multicolumn{2}{c}{ Nilai rata-rata } & \multirow{2}{*}{ Perubahan } \\
\cline { 2 - 3 } & Sebelum & Setelah & \\
\hline Permainan kearifan budaya lokal & 67,03 & 84,15 & $+17,12$ \\
Dukungan sosial & 52,83 & 72,64 & $+19,81$ \\
Senam otak & 22,45 & 51,13 & $+28,68$ \\
Ramah lansia & 48,83 & 76,41 & $+27,58$ \\
\hline
\end{tabular}

Tabel 6. Perubahan frekuensi gangguan kesehatan dan kualitas hidup lansia di Desa Purwobinangun setelah dilakukan pelatihan

\begin{tabular}{lcccccc}
\hline \multirow{2}{*}{ Gangguan kesehatan } & \multicolumn{2}{c}{$\begin{array}{c}\text { Sebelum } \\
\text { pelatihan }\end{array}$} & \multicolumn{2}{c}{$\begin{array}{c}\text { Setelah } \\
\text { pelatihan }\end{array}$} & \multicolumn{2}{c}{ Perubahan } \\
\cline { 2 - 7 } & $\mathbf{n}$ & $\mathbf{\%}$ & $\mathbf{n}$ & $\%$ & $\mathbf{n}$ & $\%$ \\
\hline Hipertensi & 52 & 65 & 45 & 56,25 & -7 & 13,46 \\
$\quad$ Ya & 28 & 35 & 35 & 43,75 & +7 & 20 \\
$\quad$ Tidak & & & & & & \\
Diabetes Melitus (DM) & 37 & 46,25 & 37 & 46,25 & 0 & 0 \\
$\quad$ Ya & 43 & 53,75 & 43 & 53,75 & 0 & 0 \\
$\quad$ Tidak & & & & & & \\
Kecenderungan depresi & 57 & 71,25 & 39 & 48,75 & -18 & 31,57 \\
$\quad$ Ya & 23 & 28,75 & 41 & 51,25 & +18 & 43,9 \\
$\quad$ Tidak & & & & & & \\
Fungsi Kognitif & 16 & 20 & 29 & 36,25 & +13 & 44,83 \\
$\quad$ Tidak ada gangguan & 55 & 68,75 & 42 & 52,5 & -13 & 23,64 \\
$\quad$ Gangguan sedang & 9 & 11,25 & 9 & 11,25 & 0 & 0 \\
$\quad$ Gangguan berat & & & & & & \\
Kualitas Hidup & 29 & 36,25 & 51 & 63,75 & +22 & 43,13 \\
$\quad$ Tinggi & 51 & 63,75 & 29 & 36,25 & -22 & 43,13 \\
$\quad$ Rendah & & & & &
\end{tabular}


diderita oleh lansia. Selain itu, lansia berlatih melakukan senam sendi untuk mempertahankan fungsi fisiologis sendi secara optimal, mencegah secara dini terjadinya penyakit degeneratif seperti diabetes melitus, hiperurisemia, hipertensi, dan penyakit kardiovaskuler lainnya, serta mempertahankan pola tidur yang normal.

\section{Pembahasan}

Penelitian ini menunjukkan bahwa terjadi peningkatan baik pengetahuan maupun keterampilan kader setelah dilakukan pelatihan. Kader merasa sudah melakukan hal-hal yang berhubungan dengan dukungan sosial dan religius, serta ramah terhadap lansia dalam kehidupan sehari-hari, namun baru mengetahui bahwa hal tersebut merupakan salah satu cara penanggulangan gangguan kesehatan pada lansia setelah mendapatkan pelatihan.

Pemberian sentuhan dan kasih sayang yang menimbulkan kontak kulit akan meningkatkan kerja sistem saraf perifer sehingga dapat memperbaiki tekanan darah dan denyut jantung, serta menyebabkan kondisi menjadi rileks. ${ }^{5}$ Pemberian pujian kepada lansia akan meningkatkan dopamin yang bertanggungjawab terhadap sistem penghargaan sehingga lansia merasa dihargai dan dicintai oleh kader. Hal tersebut membuat lansia akan memiliki rasa percaya diri dan terhindar dari depresi. ${ }^{5}$

Lansia yang memiliki kadar oksitosin yang cukup akan mampu bersosialisasi dengan baik terhadap lingkungan sekitarnya. Penelitian terdahulu juga menyebutkan bahwa oksitosin memiliki efek anxiolytic yaitu mengurangi kecemasan. ${ }^{6}$ Dalam kegiatan pemberian dukungan sosial emosional, penghargaan, instrumental, informatif, dan spiritual, lansia mendapatkan kenikmatan berupa perasaan puas, tenang, nyaman dan damai yang akan meningkatkan dopamin. ${ }^{6}$ Lansia yang mendapatkan perasaan dihargai, dicintai, dan ditenangkan akan meningkat kadar dopaminnya. Mendapatkan kenikmatan berupa perasaan dipercaya terhadap kemampuannya dalam melakukan permainan, mampu meningkatkan hormon oksitosin. ${ }^{7}$ Dukungan sosial meningkatkan perasaan senang, dimana akan menurunkan kadar hormon kortisol. ${ }^{8}$ Peningkatan dopamin dan oksitosin, serta penurunan kadar kortisol berdampak terhadap penurunan depresi dan peningkatan imunitas. Dukungan sosial dapat memengaruhi kesehatan mental dan fisik, serta kognisi dan perilaku. ${ }^{9}$

Kegiatan dukungan spiritual akan meningkatkan motivasi lansia dalam melakukan kegiatankegiatan religius dan ritual-ritual kepercayaan. Dalam kegiatan ritual, seperti berdoa, berzikir, dan sholat berjamaah dapat menghilangkan stres, meningkatkan rasa aman, semangat, dan cinta serta menurunkan depresi pada lansia.

Kegiatan-kegiatan ritual seperti berdoa bersama, ziarah bersama, dan mengikuti upacara ritual terbukti menguatkan kepercayaan diri, meningkatkan rasa tentram, rasa aman, dan menurunkan depresi. Pelaksanaan kegiatan spiritual akan meningkatkan endorfin, serotonin, dopamin, dan melantonin, serta menurunkan kadar kortisol, sehingga dapat menurunkan risiko depresi dan meningkatkan imunitas.

Beberapa dukungan yang diberikan selama pelatihan dapat meningkatkan rasa senang dan percaya diri pada lansia tentang kesehatannya, kemampuannya dan keberhasilannya dalam membina keluarga. Dukungan sosial akan meningkatkan kualitas hidup secara fisik, psikologis, maupun sosial. Dukungan sosial instrumental akan meningkatkan rasa aman, senang dan tenang. Bentuk dukungan sosial instrumental yang diberikan kader yaitu sentuhan, pelukan, dibantu berdiri, dan digandeng. Domain psikologis yang meningkat menjadikan lansia merasa aman, senang, dan percaya diri. Lansia secara fisik merasa menjadi lebih sehat dan kuat, serta nyeri sendinya berkurang sehingga menjadikan mereka lebih aktif mengikuti kegiatan. Lansia yang secara fisik merasa sehat akan menjadi lebih berani untuk mengikuti kegiatan di masyarakat.

Kegiatan permainan berbasis kearifan budaya lokal yang dilakukan sambil menyanyi dan menari bersama memberikan keuntungan secara fisik, 
misalnya peningkatan koordinasi dan kekuatan otot. Ditinjau secara emosional, permainan berbasis kearifan budaya lokal membantu proses eksplorasi emosi seperti rasa kehilangan yang sulit diungkapkan secara verbal, kemarahan, frustasi, dan membantu lansia merasa lebih gembira. Dari segi sosial, permainan berbasis kearifan budaya lokal dapat mengurangi perasaan terisolasi dan meningkatkan keterampilan bersosialisasi. Secara mental, permainan tersebut meningkatkan keterampilan kognitif, ingatan, dan motivasi, serta mengurangi stres dan kecemasan. Permainan dan lagu tradisional yang sesuai dengan kearifan budaya lokal dan mempunyai nilai-nilai luhur dan filosofi Jawa yang sangat kuat akan meningkatkan semangat, mengurangi stres, menimbulkan perasaan senang dan meningkatkan imunitas. ${ }^{10,11}$

Peningkatan keterampilan permainan berbasis kearifan budaya lokal pada kader yandu lansia dan lansia dapat meningkatkan rasa senang, memberikan rasa gembira, menyebabkan tertawa lepas, dan dapat melepaskan stres dalam rutinitas sehari-hari sebagai ibu rumah tangga, baik bagi kader yandu, maupun para lansia. Secara teoritis kegembiraan disertai tertawa lepas dapat mempengaruhi kadar neurotransmiter dan hormon-hormon di otak. Neurotransmiter tersebut adalah dopamin, serotonin, oksitosin, dan endorfin. Dopamin berhubungan dengan kadar kepuasan dan kadarnya akan meningkatkan bila seseorang sebagai individu merasa penting bagi orang lain. Kadar oksitosin akan meningkat bila orang saling mempercayai satu sama lain. Kadar endorfin akan meningkat bila seseorang merasa bahagia dan rileks. $^{5}$

Kader yandu lansia bersama dengan lansia bermain secara berkelompok sehingga lansia mendapatkan kepuasan karena lansia mempunyai kebutuhan untuk diajak kegiatan-kegiatan, dihargai, disayang, dipuji, dan dipeluk. Harga diri pada lansia meningkat karena sebagian besar permainan yang diajarkan membutuhkan kerjasama yang baik antar lansia. Dengan demikian lansia akan merasa bahwa dirinya penting dan mampu. Adanya kerjasama ini juga menumbuhkan rasa saling percaya pada lansia. Bermain berkelompok merupakan salah satu bentuk psikoterapi kelompok. Bentuknya yag berupa self-help bertujuan untuk mendapatkan dukungan sosial, berbagi pengalaman hidup, berbagi emosi, terdapat kehomogenan dalam kelompok. ${ }^{12}$ Permainan yang menyenangkan juga menciptakan suasana yang santai dan rileks yang memengaruhi kondisi kejiwaan lansia. Semua hal tersebut terkait dengan harmonisasi keempat neurotransmiter di atas.

Permainan yang menyenangkan menyebabkan perubahan fisiologis pada beberapa sistem dalam tubuh. Sistem tersebut antar lain sistem muskuloskeletal, sistem kardiovaskular, sistem endokrin, serta sistem saraf. ${ }^{13}$ Selain itu, permainan yang menyenangkan juga menyebabkan perubahan pada sistem kerja katekolamin dan kadar kortisol sehingga memengaruhi sistem imun. ${ }^{4,13,14}$ Tertawa terbahak-bahak dapat mengurangi ketegangan otot, menurunkan tekanan darah, meningkatkan oksigenase jaringan, melatih kekuatan jantung, dan memicu produksi endorfin. Tertawa secara berkelompok lebih efektif dibanding tertawa secara individual dalam meningkatkan kesehatan. Tertawa bersama-sama dapat meningkatkan endorphin surge (Ionjakan endorfin) yang dapat ditularkan pada teman-teman yang lain. Hal ini sangat bermanfaat untuk interaksi sosial dan meningkatkan kepuasan diri. ${ }^{15}$

Pada setiap awal dan akhir permainan selalu diawali dengan berdoa dan bernapas dalam untuk pemanasan dan pendinginan. $\mathrm{Hal}$ tersebut juga dapat meningkatkan relaksasi, sehingga menurunkan depresi. Bernapas dalam meningkatkan sinkronisasi sistem cardiorespiratory, memodulasi autonomic nervous system dan aktivitas amigdala, mempertahankan homeostasis di seluruh tubuh termasuk otak, serta memengaruhi kadar dan respons neurotransmiter yang dapat mengurangi atau mencegah mood negative. ${ }^{16}$ Pemberian sentuhan dan pujian setiap selesai permainan akan meningkatkan rasa percaya diri, dihargai, senang, dan semangat, serta meningkatkan endorfin dan menurunkan depresi. ${ }^{17}$ Permainan kearifan budaya lokal dapat 
menurunkan depresi, meningkatkan fungsi kognitif, dan meningkatkan kualitas hidup..$^{11,18}$

Pelatihan bersikap ramah terhadap lansia memberisi cara memberikan senyuman dengan penuh empati dan memberikan sapaan salam, serta sentuhan yang baik dan santun. Senyum, sapaan, salam, dan sentuhan yang diberikan dengan tulus pada lansia akan meningkatkan rasa senang, tenang, aman, dan percaya diri, serta meningkatkan hormon endorfin, serotonin, dopamin, dan oksitosin, yang pada akhirnya akan meningkatkan kesehatan mental dan fisik.

Gerakan-gerakan yang dilakukan dalam senam otak dapat memberikan rangsangan yang adekuat untuk memacu fungsi otak. Rangsangan yang diberikan pada dimensi lateral akan mengoptimalkan fungsi-fungsi hemisfer otak yang berhubungan erat dengan fungsi kognitif. Rangsangan yang ditimbulkan pada dimensi pemusatan dapat meningkatkan hubungan antar neuron sehingga dapat membantu lansia terhindar dari kemunduran fungsi kognitif. ${ }^{3}$ Dimensi pemusatan dapat mengoptimalkan komunikasi antara sistem limbik yang berperan dalam informasi emosional dengan serebrum yang berfungsi dalam pemikiran abstrak. Gerakan-gerakan tersebut dapat mengaktifkan ingatan dan daya pikir yang melibatkan sistem limbik dan serebrum. ${ }^{3}$ Keempat hal yang dilatihkan dapat meningkatkan kesehatan fisik, menurunkan depresi, meningkatkan fungsi kognitif, dan meningkatkan kualitas hidup.

\section{Kesimpulan}

Pelatihan penanggulangan gangguan kesehatan lansia yang terdiri dari pelatihan permainan berbasis kearifan budaya lokal, dukungan sosial dan religius, senam otak, serta cara bersikap ramah pada kader yandu lansia di Desa Purwobinangun dapat meningkatkan pengetahuan dan keterampilan kader yandu lansia dalam penanggulangan gangguan kesehatan fisik, kecenderungan depresi, dan gangguan fungsi kognitif, serta meningkatkan kualitas hidup pada lansia. Peningkatan pengetahuan dan keterampilan kader yandu lansia di Desa Purwobinangun dapat meningkatkan kesehatan fisik, menurunkan kecenderungan depresi, meningkatkan fungsi kognitif, dan meningkatkan kualitas hidup lansia.

\section{Ucapan terima kasih}

Penulis mengucapkan terima kasih kepada Prof. dr. Ova Emilia, M.Med.Ed, Sp.OG(K), Ph.D selaku Dekan FK-KMK UGM, dr. Yodi Mahendradhata, M.Sc., Ph.D selaku Wakil Dekan Bidang Penelitian dan Pengembangan, dan dr. Mei Neni Sitaresmi, Ph.D, Sp.A(K) selaku Wakil Dekan Bidang Kerjasama, Alumni, dan Pengabdian kepada Masyarakat FKKMK UGM yang telah memberikan dana dan izin penelitian ini

Kami juga ucapkan terima kasih kepada Bapak Heri Suasana sebagai Kepala Desa Purwobinangun yang telah memberikan izin dan tempat, serta mengerahkan warganya untuk membantu kelancaran penelitian ini serta kepada kader yandu lansia, dan para lansia yang telah menjadi subjek penelitian ini, kami ucapkan banyak terima kasih.

\section{Konflik kepentingan}

Penulis menyatakan tidak ada konflik kepentingan dengan pihak-pihak yang terkait dalam penelitian ini.

\section{Daftar pustaka}

1. Pusat Data dan Informasi Kemenkes. Infodatin Lansia : Situasi Lanjut Usia di Indonesia. Kementrian Kesehatan RI. 2016.

2. Badan Pusat Statistik. Statistik Penduduk Lanjut Usia. Statistik Indonesia. 2016

3. Faham $M$, Sagiran. Pengaruh Brain Gym terhadap Fungsi Kognitif pada Usia Lanjut. Mutiara Medika Jurnal Kedokteran dan Kesehatan. 2009; 9(2): 86-94.

4. Hubert W. De Jong MR. Autonomie, Neuroendocrine, And Subjective Responses To Emotion Inducing Film Stimuli. Int J Psychophysiol. 1991; PP 73-93.

5. StahISM.Stahl's Essential Psychopharmacology: 
Neuroscientific Basis and Practical Applications, $3^{\text {rd }}$ edition. New York: Cambridge University Press. 2008.

6. Camara E, Forlena AR, Munte TF. Reward Network In The Brain As Captured By Connectivity Measures. Front Neurosci. 2009; 3(3): 350-360.

7. Miyazaki T, Takase K, Nakajima W, Tada H, Ohya D, Sano A, Goto T. Disrupted Cortical Function Underlies Behavior Disfunction Due to Social Isolation. J Clin Invest, 2012 July; 122 (7): 26902701.

8. McEwen BS, Mirsky AE, Hatch MM. Physiologi and Neurobiology of Stress and Adaptation Central Role Of The Brain. Psysiol. 2017; 87 : 873-904.

9. McCorkle B, Tugers ES, Dunn EC, Wan YM. Increasing Social Support For Individuals With Serious Mental Illness: Evaluating The Compeer Model Of Intentional Friendship. Community Ment Health J; 2008.

10. Hartoto. Pedidikan Rekreasi. FPOK IKIP Yogyakarta. 1995.

11. Sumarni DW. Pengaruh Permainan Humor Kearifan Budaya Lokal dan Dukungan Spiritual terhadap Depresi, Gangguan Interaksi Sosial, Gangguan Kognitif dan Kualitas Tidur Lansia di Huntap Gondang Kabupaten Sleman. Laporan Penelitian. Fakultas Kedokteran, Kesehatan Maysrakat, dan Keperawatan Universitas Gadjah Mada. 2012.

12. Kaplan HL, Friedman AM, Sadock BJ. Comprehensive Textbook of Psychiatry, William Wilkins, Baltimore. 2017.

13. Fry, William F. The Biology Of Humor. Int J Humor Res. 2004; 7(2): 111-126

14. McDaniel ND. Touching Makes You Healthier. Health Magazine. 2011 [Cited 20 Agustus 2018]. Available from: http://edition.cnn. com/2011/HEALTH/01/05/touching.makes. you.healtier.health/index.htm>

15. Akbaraly TN, Ancelin M, Jaussent I. Metabolic Syndrome and Onset of Depressive Symptoms in the Elderly.Diabetes Care. 2011; 34: 904-909.

16. Jerath R. Self-regulation of Breathing as a Primary Treatment for Anxiety. Appl Psychophysiol Biofeedback. 2015;40(2):107-15

17. Niel RC. Physiologi of Behavior $8^{\text {th }}$. Boston. America. 2004.

18. Sumarni, Identifikasi Gangguan Mental, Gangguan Reproduksi, dan Faktor-Faktor yang Mempengaruhi, Serta Upaya Penanganannya pada Remaja SLTP Pasca Erupsi Merapi di Kabupaten Sleman. Laporan Penelitian. Fakultas Kedokteran, Kesehatan Maysrakat, dan Keperawatan Universitas Gadjah Mada. 2014. 